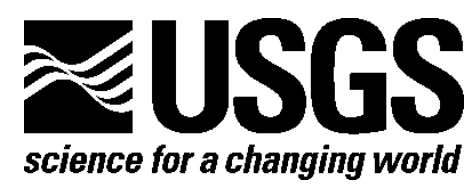

\title{
A Preliminary Deposit Model for Lithium Brines
}

By Dwight Bradley, LeeAnn Munk, Hillary Jochens, Scott Hynek, and Keith Labay

Open-File Report 2013-1006

U.S. Department of the Interior

U.S. Geological Survey 


\section{U.S. Department of the Interior \\ KEN SALAZAR, Secretary}

\section{U.S. Geological Survey \\ Marcia K. McNutt, Director}

U.S. Geological Survey, Reston, Virginia: 2013

For more information on the USGS—-the Federal source for science about the Earth, its natural and living resources, natural hazards, and the environment-visit http://www.usgs.gov or call 1-888-ASK-USGS

For an overview of USGS information products, including maps, imagery, and publications, visit $h t t p: / / w w w . u s g s . g o v / p u b p r o d$

To order this and other USGS information products, visit http://store.usgs.gov

Suggested citation:

Bradley, Dwight, Munk, LeeAnn, Jochens, Hillary, Hynek, Scott, and Labay, Keith, 2013, A preliminary deposit model for lithium brines: U.S. Geological Survey Open-File Report 2013-1006, 6 p.

Any use of trade, firm, or product names is for descriptive purposes only and does not imply endorsement by the U.S. Government.

Although this information product, for the most part, is in the public domain, it also may contain copyrighted materials as noted in the text. Permission to reproduce copyrighted items must be secured from the copyright owner. 


\section{Contents}

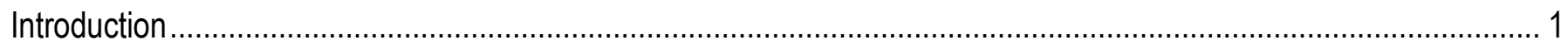

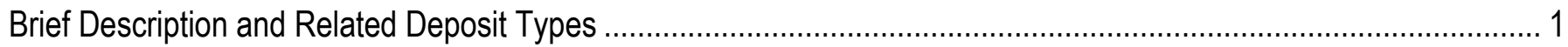

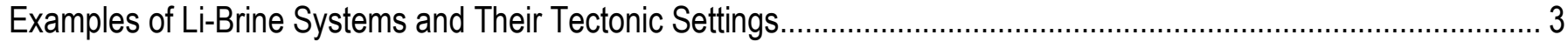

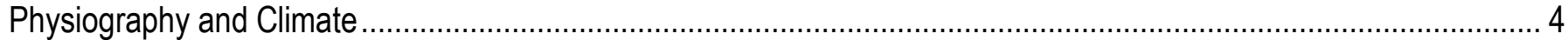

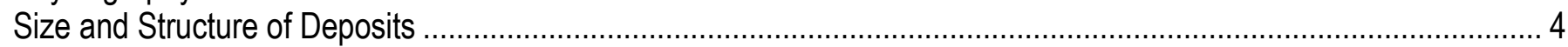

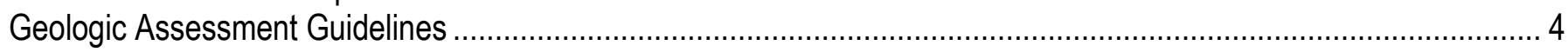

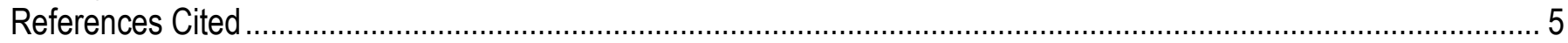

\section{Figures}

1. Schematic deposit model for lithium brines

2

2. World map of lithium brine deposits, detail in South America, and histogram showing the bimodal latitudinal distribution of Li-brine deposits in northern and southern arid belts. 


\title{
A Preliminary Deposit Model for Lithium Brines
}

\author{
By Dwight Bradley, LeeAnn Munk, Hillary Jochens, Scott Hynek, and Keith Labay
}

\section{Introduction}

This report is part of an effort by the U.S. Geological Survey to update existing mineral deposit models and to develop new ones. The global transition away from hydrocarbons toward energy alternatives increases demand for many scarce metals. Among these is lithium, a key component of lithium-ion batteries for electric and hybrid vehicles. Lithium (Li) brine deposits account for about three-fourths of the world's lithium production (U.S. Geological Survey, 2011). Updating an earlier deposit model by Asher-Bolinder (1991), we emphasize geologic information that might directly or indirectly help in exploration for lithium brine deposits, or for assessing regions for mineral resource potential. Special attention is given to the best-known deposit in the world-Clayton Valley, Nevada (Kunasz, 1974; Davis and others, 1986; Price and others, 2000; Zampirro, 2004); Munk and others (2011a, b) - and to the giant Salar de Atacama, Chile (Risacher and others, 2003; Lowenstein and Risacher, 2009).

\section{Brief Description and Related Deposit Types}

Lithium brine deposits are accumulations of saline groundwater that are enriched in dissolved lithium. For this report, we focus on brines in closed basins in arid regions, where lithium salts can be extracted at a profit. This process is as follows (Garrett, 2004). Brine, typically carrying 200-1,400 milligrams per liter $(\mathrm{mg} / \mathrm{l}) \mathrm{Li}$, is pumped to the surface and concentrated by evaporation in a succession of artificial ponds, each one in the chain having a greater Li concentration. After a few months to about a year, depending on climate, a concentrate of 1 to 2 percent $\mathrm{Li}$ is further processed in a chemical plant to yield various end products, such as lithium carbonate and lithium metal.

All producing lithium brine deposits share a number of first-order characteristics: (1) arid climate; (2) closed basin containing a playa or salar; (3) tectonically driven subsidence; (4) associated igneous or geothermal activity; (5) suitable lithium source-rocks; (6) one or more adequate aquifers; and (7) sufficient time to concentrate a brine. Key aspects of the proposed lithium-brine deposit model are shown in figure 1; some of these will be elaborated below. In essence, lithium is liberated by weathering or derived from hydrothermal fluids from a variety of rock sources within a closed basin. Circumstantial evidence from Clayton Valley suggests that felsic vitric tuffs are a particularly favorable primary source (Price and others, 2000). In our view, another potentially important lithium source in Clayton Valley is uplifted Neogene lake beds from earlier in the basin's history, which had previously been hydrothermally altered to hectorite (see also Kunasz, 1974). Lithium is highly soluble and, unlike sodium $(\mathrm{Na})$, potassium $(\mathrm{K})$, or calcium $(\mathrm{Ca})$, does not readily produce evaporite minerals when concentrated by evaporation. Instead it ends up in residual brines in the shallow subsurface. Economic brines have Li concentrations in the range of 200 to 4,000 milligrams per liter (mg/l) (Gruber and others, 2011; Kesler and others, 2012). Other elements in solution, such as boron and potassium, may be recovered as byproducts or coproducts; brines can also contain undesirable 
elements that create problems in processing (magnesium) or toxic elements that require care in waste disposal (Garrett, 2004).

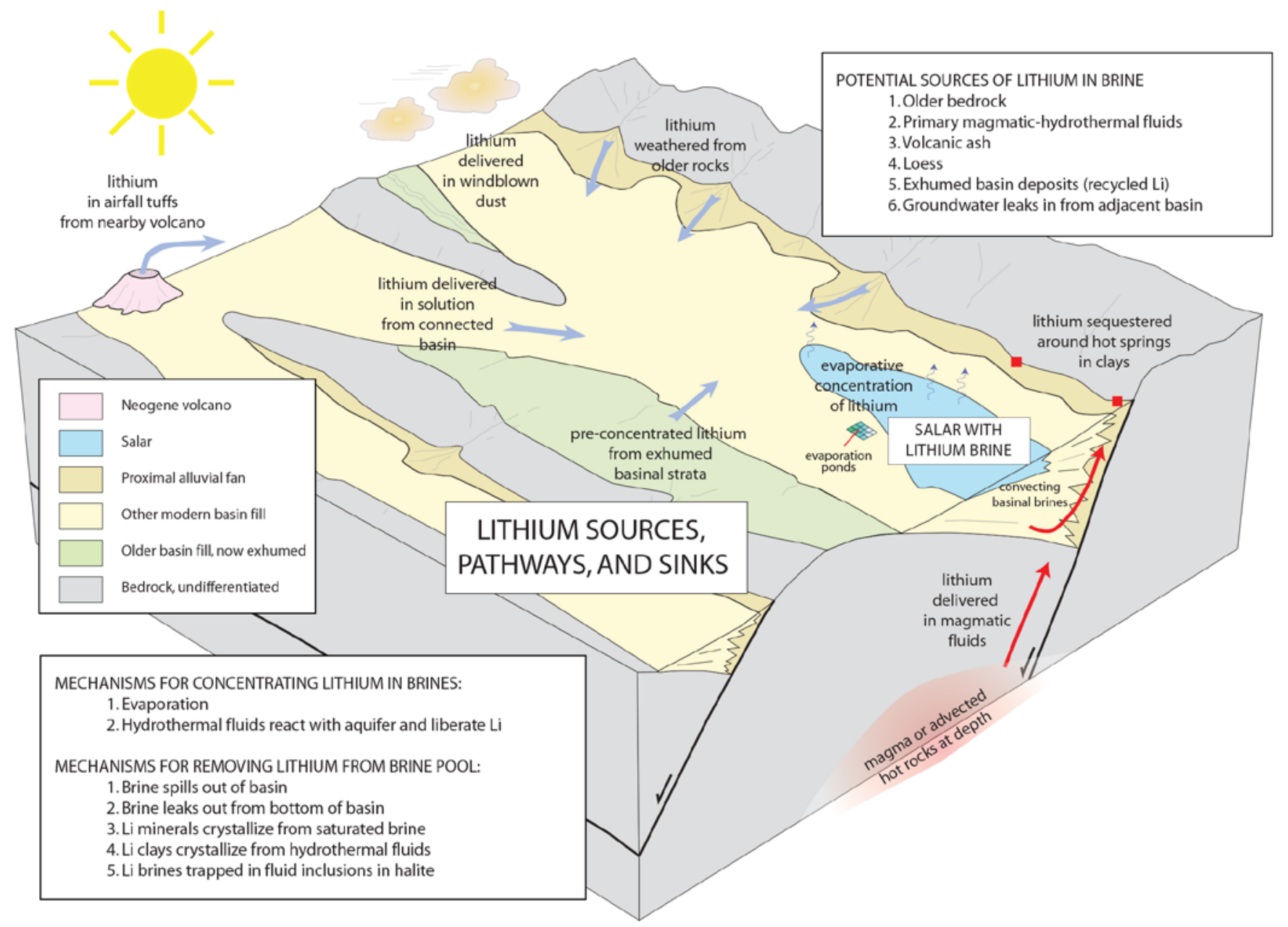

Figure 1. Schematic deposit model for lithium brines showing part of a closed-basin system consisting of interconnected subbasins. The subbasin containing the salar is the lowest.

A number of similar and related deposit types are seen. Some ancient oilfield brines are enriched in lithium (Collins, 1976, reported $692 \mathrm{mg} / 1$ in the Smackover brine of Texas). Unless located in an arid climate, recovery of $\mathrm{Li}$ in evaporation ponds is not economically feasible. Brines in a spectrum of closed-basin settings can be enriched in potassium chloride $(\mathrm{KCl})$, calcium chloride $\left(\mathrm{CaCl}_{2}\right)$, bromine (Br), and iodine (I) (Warren, 2010) — the differences reflecting bedrock chemistry (Eugster, 1980) and perhaps also hydrothermal contributions. Most lithium brine fields are spatially associated with sodium chloride $(\mathrm{NaCl})$ evaporite deposits, but the reverse is not necessarily true - that is, most $\mathrm{NaCl}$ evaporites lack an associated lithium brine. Hydrothermal lithium-clay deposits (for example, hectorite) are commonly found in the same basins as lithium brines, and there is reason to suspect that they are cogenetic (Vine, 1980). Lithium-brine deposits are commonly associated with borate mineralization in arid, closed basins; the latter appear to be hybrids involving both hydrothermal and evaporative processes. 


\section{Examples of Li-Brine Systems and Their Tectonic Settings}

All closed-basin lithium-brine deposits that are of present economic interest are of Quaternary age. Basins that contain lithium-enriched brines have a number of different tectonic origins (fig. 2). Quantities of $\mathrm{Li}$ in million metric tons (Mt) in the following discussion are from Kesler and others (2012). Clayton Valley, Nevada, (0.2 Mt of Li) is located within the Basin and Range extensional province of the western United States; in detail, it is hosted in an extensional half-graben system between a young metamorphic core complex and its breakaway zone (Oldow and others, 2009). The Salar de Atacama (6.3 Mt of Li) and Salar de Uyuni (10.2 Mt of Li) are located on the Altiplano of Chile and Bolivia, a high, internally drained plateau along the crest of the Andean convergent-margin orogen that includes a number of closed basins; the basin of the Salar de Atacama itself is a contractional intrarc basin. The Salton Sea, California, is a strike-slip basin located at a releasing bend along an intracontinental segment of the San Andreas transform fault. Zabuye Lake (1.5 Mt of Li) is one of a family of closed basins in the Tibetan plateau on the upper plate of the Himalayan-Tibetan collisional orogen; in detail, it is a Neogene graben at high angles to the structural grain of the orogen. Curiously, and due partly to extreme aridity, most of these example deposits are in globally exceptional tectonic settings: the Basin and Range is the world's widest extensional province, the Altiplano is the highest sector of a continental-margin arc, and Tibet is the largest and highest syncollisional plateau.

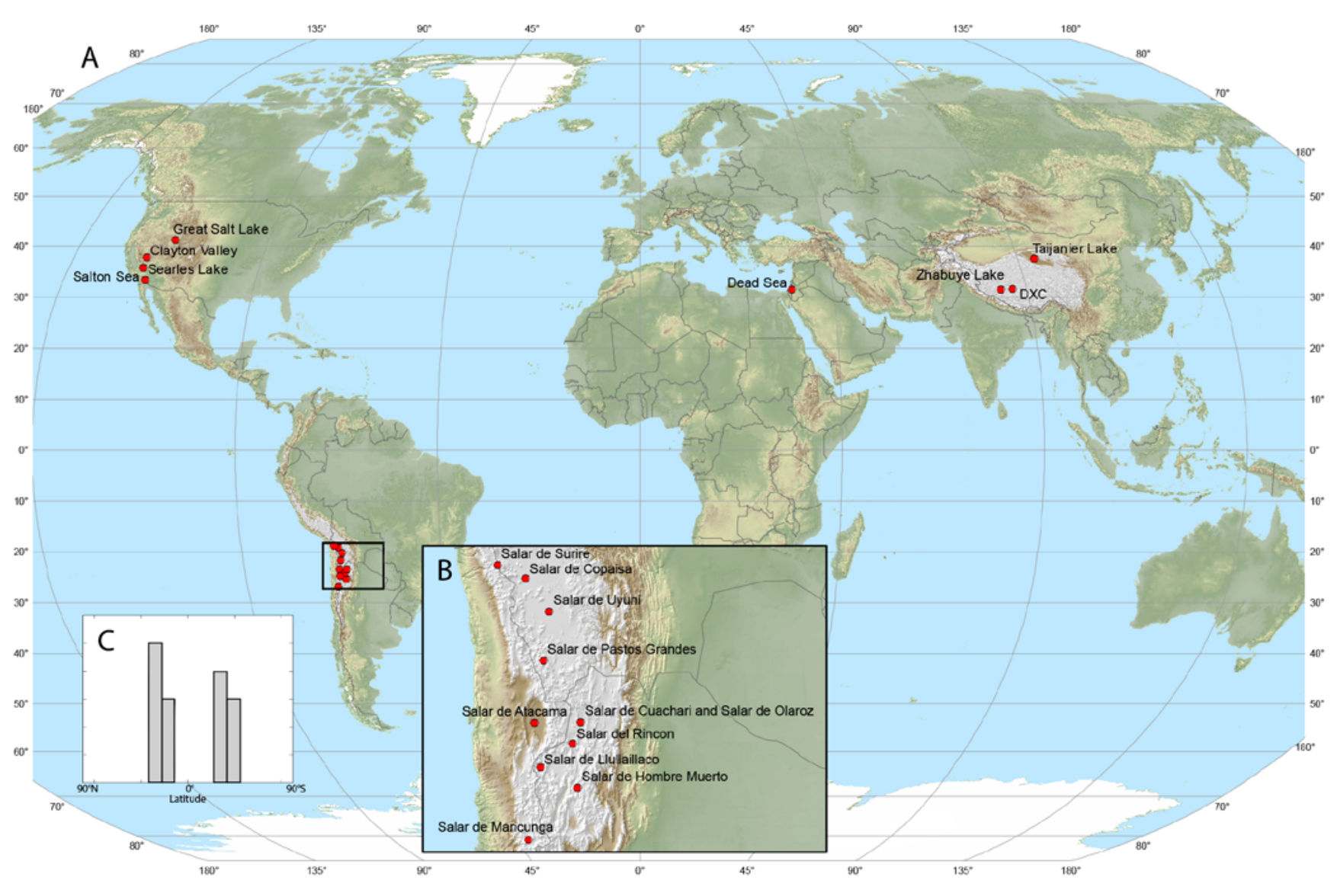

Figure 2. (A) World map of lithium brine deposits (red dots). (B) Detail in South America. (C) Histogram showing the bimodal latitudinal distribution of $\mathrm{Li}$ brine deposits in northern and southern arid belts. 


\section{Physiography and Climate}

The single most important factor determining if a nonmarine basin can accumulate lithium brine is whether or not the basin is closed. Closed basins form because of tectonics but they are maintained only where, over longer time-spans, evaporation exceeds precipitation. If the long-term rate of precipitation in a basin increases sufficiently, eventually lake water will overtop some point along the drainage divide and drain away, carrying with it any dissolved lithium. Of the basins shown on the world map, 3 are classed as semi-arid, 11 as arid, and 1 as hyperarid (http://csi.cgiar.org/Aridity/). Globally, lithium brines occur in the arid latitudinal belts on either side of the equator (fig. 2C), with the favorable zones lying between about $19^{\circ}$ and $37^{\circ}$ north or south. Rain-shadow effects probably stretch the north-south span of favorable latitudes.

\section{Size and Structure of Deposits}

Basins that host lithium brines range in area by more than three orders of magnitude. The floor of Salar de Uyuni has an area of about 14,000 square kilometers $\left(\mathrm{km}^{2}\right)$ and a total catchment of about $47,000 \mathrm{~km}^{2}$. At the other end of the spectrum, the floor of Clayton Valley has an area of about $100 \mathrm{~km}^{2}$ and a catchment of about $1,400 \mathrm{~km}^{2}$ (areas were measured using ARC-GIS from a global 90-m SRTM DEM). Clayton Valley is the topographically lowest of at least five adjacent basins that are hydrologically linked by groundwater flow (Zampirro, 2004). In this case, it is the combined area of all five linked catchments that matters, making the effective area of the Clayton Valley Li-brine system much larger.

Active faulting appears to be involved in all lithium basins. Fault-related subsidence creates accommodation space, without which only a thin veneer of basin sediments could accumulate. A thick basin fill is needed to provide an aquifer of sufficient volume to hold a viable brine resource. In contrast, shallow, superficial basins in cratonic regions such as the Sahara Desert lack fault control and are not known to be prospective for lithium brines. Some basins are cut by active intrabasinal faults. Brine pools in Clayton Valley and Salar de Atacama are localized along active intrabasinal faults that control the distribution of aquifers and also influence groundwater movement patterns. These intrabasinal faults are known from boreholes and have no surface expression (Zampirro, 2004; Jordan and others, 2002).

Because they are contained by aquifers of various geometries, lithium brines are localized in the subsurface rather than being present everywhere at depth. At Salar de Atacama, the brine is hosted in the porous, upper 30 meters of the salar's halite nucleus (Garrett, 2004). Little is known about the potential of brine aquifers at depth in Salar de Atacama. At Clayton Valley, brines are pumped from six gently dipping aquifers that are variously composed of ash, fanglomerate, tufa, and halite (Zampirro, 2004).

\section{Geologic Assessment Guidelines}

Characteristics that appear to be essential for lithium resource potential are an arid climate and a closed, tectonically active basin. Another likely requirement — or at least a favorable characteristic — is elevated heat flow as evident from young volcanoes or hot springs. Source rocks such as felsic, vitric tuffs that have abundant and readily leached lithium are favorable but perhaps not essential, since lithium is present in most crustal rocks at tens of parts per million (ppm). Another favorable indication of lithium brines is the existence of hectorite, a mineral that can be detected using ASTER remote sensing (B. Rockwell, USGS, written commun., 2010). 


\section{References Cited}

Asher-Bolinder, Sigrid, 1991, Descriptive model of lithium-rich playa brine: U.S. Geological Survey Open-File Report 91-11A, p. 53-54.

Collins, A.G., 1976, Lithium abundance in oilfield waters: U.S. Geological Survey Professional Paper 1005, chap. 27, p. 116-122. (Also available at http://pubs.usgs.gov/pp/1005/report.pdf).

Davis, J.R., Friedman, Irving, and Gleason, J.D., 1986, Origin of the lithium-rich brine, Clayton Valley, Nevada: U.S. Geological Survey Bulletin 1622, p. 131-138. (Also available at

http://pubs.usgs.gov/bul/1622/report.pdf).

Eugster, H.P., 1980, Geochemistry of evaporitic lacustrine deposits: Annual Review of Earth and Planetary Sciences, v. 8, p. 35-63.

Garrett, D.E., 2004, Handbook of lithium and natural calcium chloride-Their deposits, processing, uses and properties ( $1^{\text {st }}$ ed.): Amsterdam; Boston: Elsevier Academic Press, 476 p.

Gruber, P.W., Medina, P.A., Keoleian, G.A., Kesler, S.E., Everson, M.P., and Wallington, T.J., 2011, Global lithium availability-A constraint for electric vehicles?: Journal of Industrial Ecology, v. 15, no. 5, p. 760-775.

Jordan, T.E., Munoz, N., Hein, M.C., Lowenstein, T.K., Godfrey, L.V., and Yu, J., 2002, Active faulting and folding without topographic expression in an evaporite basin, Chile: Geological Society of America Bulletin, v. 114, no. 11, p. 1,406-1,421.

Kesler, S.E., Gruber, P.W., Medina, P.A., Keoleian, G.A., Everson, M.P., and Wallington, T.J., 2012 , Global lithium resources-Relative importance of pegmatite, brine and other deposits: Ore Geology Reviews, v. 48 p. 55-69. (Also available at $h t t p: / / d x . d o i . o r g / 10.1016 / j . o r e g e o r e v .2012 .05 .006$ ).

Kunasz, I.A., 1974, Lithium occurrence in the brines of Clayton Valley Esmeralda County, Nevada, in Coogan, A.H., ed., Fourth International Symposium on Salt, Houston, Tex., April 8-12, 1973, Proceedings: Cleveland, Northern Ohio Geological Society, p. 57-65. (Also available at http://www.saltinstitute.org/content/download/1270/7052).

Lowenstein, T.K., and Risacher, Francois, 2009, Closed basin brine evolution and the influence of Ca$\mathrm{Cl}$ inflow waters - Death Valley and Bristol Dry Lake California, Qaidam Basin, China, and Salar de Atacama, Chile: Aquatic Geochemistry, v. 15, no. 1, p. 71-94.

Munk, L.A., Bradley, D.C., Hynek, S.A., and Chamberlain, C.P., 2011 a, Origin and evolution of Li-rich brines at Clayton Valley, Nevada, USA [abs.]: AGU Annual Meeting, accessed September 25, 2012 , at http://static.coreapps.net/agu2011/html/V13B-2602.html.

Munk, L.A., Jennings, M., Bradley, D., Hynek, S., Godfrey, L., and Jochens, H., 2011b, Geochemistry of lithium-rich brines in Clayton Valley, Nevada, USA: SGA $11^{\text {th }}$ Biennial Meeting, Antofagasta, Chile (expanded abstract), 3 p., accessed December 11, 2012, at https://sga.conferenceservices.net/resources/1054/2590/pdf/SGA2011_0282.pdf.

Oldow, J.S., Elias, E.A., Ferranti, L., McClelland, W.C., and McIntosh, W.C., 2009, Late Miocene to Pliocene synextensional deposition in fault-bounded basins within the upper plate of the western Silver Peak-Lone Mountain extensional complex, west-central Nevada, in Oldow, J.S., and Cashman, P.H, eds., Late Cenozoic structure and evolution of the Great Basin-Sierra Nevada transition: Boulder, Colo., The Geological Society of America, Special Papers 2009, v. 447, p. 275-312, doi: 10.1130/2009.2447(14). (Also available at http://specialpapers.gsapubs.org/content/447/v.full.pdf+html).

Price, J.G., Lechler, P.J., Lear, M.B., and Giles, T.F., 2000, Possible volcanic source of lithium in brines in Clayton Valley, Nevada, in Cluer, J.K., Price, J.G., Struhsacker, E.M., Hardyman, R.F., and Morris, C.L., eds., Geology and ore deposits 2000-The Great Basin and beyond: Geological Society of Nevada Symposium, May 15-18, 2000, [Proceedings], p. 241-248. 
Risacher, F., Alonso, H., Salazar, C., 2003, The origin of brines and salts in Chilean salars-A hydrochemical review: Earth-Science Reviews, v. 63, nos. 3-4, p. 249-293.

U.S. Geological Survey, 2011, Mineral commodity summaries 2011: U.S. Geological Survey, 198 p. (Also available at http://minerals.usgs.gov/minerals/pubs/mcs/2011/mcs2011.pdf).

Vine, J.D., 1980, Where on Earth is all the lithium?: U.S. Geological Survey Open-File Report 801234, $107 \mathrm{p}$.

Warren, J.K., 2010, Evaporites through time-Tectonic, climatic and eustatic controls in marine and nonmarine deposits: Earth-Science Reviews, v. 98, no. 3, p. 217-268.

Zampirro, D., 2003, Hydrogeology of Clayton Valley brine deposits, Esmeralda County, Nevada, in Castor, S.B., Papke, K.P., and Meeuwig, R.O., eds., Proceedings of the $39^{\text {th }}$ Forum on the Geology of Industrial Minerals, May 18-24, 2003: Nevada Bureau of Mines and Geology Special Publication 33, p. 271-280. 